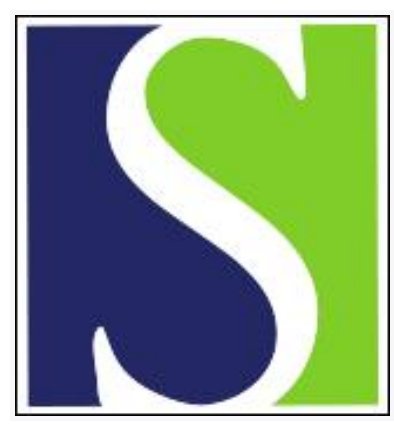

Scand J Work Environ Health 1999;25(6):541-549

https://doi.org/10.5271/sjweh.478

Issue date: Dec 1999

Parental exposure, adverse pregnancy and offspring effects perspectives in developmental epidemiolgy

by Kristensen $P$

Key terms: birth defect; birthweight; environmental exposure; festational age; fetal death; fetal growth; postnatal disease; reproductive history; study design; study validity

This article in PubMed: www.ncbi.nlm.nih.gov/pubmed/10884151

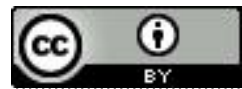




\title{
Parental exposure, adverse pregnancy and offspring effects - perspectives in developmental epidemiology
}

\author{
by Petter Kristensen, $M D^{1}$
}

\begin{abstract}
Kristensen P. Parental exposure, adverse pregnancy and offspring effects - perspectives in developmental epidemiology. Scand J Work Environ Health 1999;25(6, special issue):541-549.

Developmental health is governed by biology and the societal culture that shapes family planning. This context should not be ignored in epidemiologic studies that address the effect of parental exposure from environmental and occupational agents on prenatal development, growth and survival, on adverse birth effects, or on postnatal events. It is important to have a thorough basic knowledge of developmental health in the population under study and to consider this basis in study design and performance. One way of accomplishing this task is to combine strengths of population-based cohort studies and nested case-control studies. Sibship-based cohorts and case-control studies that make use of biomarkers may provide particular advantages. Future research on the impact of parental exposure should be more strongly based on biological knowledge about the genetic, immune, and endocrine regulation of prenatal growth and development.
\end{abstract}

Key terms birth defects, birthweight, environmental exposure, fetal death, fetal growth, gestational age, postnatal disease, reproductive history, study design, study validity.

Reproductive failure is of serious concern both for families and society. The impact of adverse environmental exposures on reproductive health has been focused on (1), but still we know little about preventable causes.

This paper deals with research in developmental epidemiology on parental exposures to environmental and occupational agents, and the exposure impact on the conceptus from clinical pregnancy is recognized until birth, and postnatally. This frame is close (but not identical) to that of reproductive toxicology (2). Method-wise, studies on pregnancy outcome before its clinical recognition are closely linked to fertility studies and are covered by Bonde in this issue (3). Parental exposure could affect the conceiving spermatozoon or oocyte or their precursors or the stem cells from which they originated, so exposure could cover a period from the parents' own fetal life until conception of their offspring. Maternal exposure can act during pregnancy or postnatally during lactation. Manifestations of adverse outcomes could occur at any point in the life-span of the offspring; during pregnancy, delivery, or the postnatal period including adolescence and adulthood: death (spontaneous abortion, stillbirth, postnatal death), structural abnormalities (birth defects), and alterations in growth or functional competence of organ or organ systems (birthweight, nervous system development, cancer). Chronic disease in adult life could be a result of parental exposure, a concept based on the "programming hypothesis" of Barker and his colleagues (4).

The objective of this paper is not to provide a review, but rather to point out research needs and future directions of design and performance in epidemiology. Reproductive health is governed by biology, and the societal culture that shapes family planning. The impact of parental exposure cannot be understood without a basic knowledge of these contexts. Furthermore, specific validity concerns are of crucial importance. Therefore, I will first outline some aspects of family planning, biology, and validity matters.

\section{Family planning aspects of developmental health}

Declining infant mortality and societal changes have altered childbearing habits profoundly throughout this century (5). The current reproductive pattern in developed countries is still influenced by cultural and social conditions. One recent and substantial change is the postponing of women's reproductive career. In Norway, the

1 National Institute of Occupational Institute, Oslo, Norway.

Reprint requests: Dr Petter Kristensen, National Institute of Occupational Health, PO Box 8149 Dep, N-0033 Oslo, Norway. [Email: petter.kristensen@stami.no] 
proportion of primiparous women $\geq 30$ years of age increased from about $5 \%$ to $15 \%$ between 1970 and 1990 (6). Combined with new developments in assisted fertilization techniques, this has resulted in a considerable increase in multiple pregnancies in several countries $(7$, 8).

Family planning is also influenced by past reproductive history. Bjerkedal \& Erickson (9) demonstrated that a subsequent pregnancy was more likely to follow among mothers who have experienced death of a previous infant than among mothers of surviving infants. Mothers with 2 children of the same gender were also more likely to have another pregnancy than mothers with 2 opposite-gendered children (9). A subsequent pregnancy is more likely for a woman who has experienced spontaneous abortion (10), whereas birth defects may have the opposite effect (11).

\section{Biological aspects of developmental health}

Pregnancy involves biological processes that are timed and regulated in complex fashions. These processes involve development of parental germ cells, interaction between conceptus and mother to ensure the implantation and establishment of the placenta, biological processes within the mother and fetus that result in appropriate growth and development, and successful parturition. Development is dependent on genetic regulation and the intricate regulation and maternal redirection of immune and endocrine balance during pregnancy.

\section{Heterogeneity}

Epidemiologic studies have documented strong variability between women for most developmental outcomes. This propensity is manifested as differing probabilities of repeating pregnancy outcomes and, on the basis of past reproductive history, the identification of subgroups with heterogeneity in underlying risk. Such heterogeneity has been demonstrated for spontaneous abortion $(10,12$ 15), perinatal mortality (16-18), gestational age (1921 ), and birthweight and fetal growth $(22,23)$. It is not surprising that these manifestations of fetal growth and survival are interrelated $(20,22,24-26)$. Recurrence has also been shown for birth defects (27). Repeating patterns of fetal growth and survival also extend across generations. Intergenerational birth record linkages demonstrate that birthweight is correlated between mother and child (28-30). Furthermore, offspring survival is dependent on maternal birthweight (30).

The biological basis for heterogeneity in fetal growth and survival is not fully understood. Seemingly, it does not represent a dichotomy where some mothers are doomed and others are protected $(31,32)$. Although the basis for heterogeneity could be exogenous, it is probably explained by stable endogenous components involving genetic, immune, and endocrine expression and regulation. A biomarker of heterogeneity has still not been found, but, if it is, it could have profound implications in the study of environmental exposure effects, given the exposure effects resulting from concerted action with the biological factors in question (33).

\section{Germ cells and genes}

Environmental mutagens can act on parental germ cells or transplacentally and cause embryonic loss, birth defects or transgeneration cancer (34-36). Although this has been a traditional conceptual frame, the supportive evidence from humans is scarce. This is particularly the case for male-mediated developmental effects $(37,38)$, in spite of the male being more prone than the female for mutagenic germ cell alterations that are compatible with successful conception (39). Furthermore, male-mediated postconception effects are easily accomplished in animal assays (40).

Genomic imprinting, parent-specific epigenetic marking of genes that results in monoallelic expression, has more recently been focused on as a potential mechanism for paternal influence on fetal growth and development (41). Clinical and experimental data suggest that the paternal genome is essential for placental development, whereas the maternal genome is essential for fetal growth regulation (42). Imprinting could play a role in the placental development and regulation of growth factors (43-46), but investigations of environmental agent influences are still lacking.

Gene-environment interaction is a rapidly growing branch of cancer research. The rationale for interaction is the hypothesis that allelic subtypes of genes that play a role in genetic or metabolic regulation influence the individual's susceptibility towards environmental agents. More recently, this interest has been extended to developmental effects as well (47). The discovery of periconceptional folic acid deficiency as a preventable cause of neural tube defects $(48,49)$, and the investigations that followed on the role of allelic subtypes in folic acid metabolism $(50,51)$ boosted further birth defect studies. One example is pursuit of the hypothesis that folic acid deficiency and maternal smoking during pregnancy cause facial clefts and that the risk from vitamin deficiency or fetal tobacco exposure is influenced by genotype (5261). The questions have still not been answered, but the problems have accelerated the development of both epidemiologic designs and genetic susceptibility markers $(62,63)$.

\section{Endocrine and immune factors}

Normal intrauterine development and growth are dependent on endocrine and immune regulation and adaptation. The processes involve both mother and offspring, and the 
placenta plays a crucial role (64). Prenatal exposure to endocrine-disrupting xenobiotics are hypothesized to interfere with normal regulation and to cause genital birth defects and hormone-dependent cancer in adult life (65, 66). The maternal immune system is redirected in pregnancy and shifts balance from a predominant Th1-driven cell-mediated immunity toward Th2-driven humoral immunity (67). Dysregulation of this equilibrium may constitute a threat to fetal survival and growth $(67-69)$. Antiphospholipid antibodies are the only well-substantiated humoral causes of pregnancy loss or growth retardation (69-70). Immunogenetic manifestations (allelic HLA subtypes) have been linked with habitual abortion (71). Considering the vast knowledge of immune effects from environmental factors, it is strange that virtually no study has addressed immune effects from environmental agents as a mechanism of developmental effects.

\section{Validity issues in developmental epidemiology}

I will emphasize some validity aspects and refer to textbooks (72) for more comprehensive reviews.

\section{Selective loss}

The appropriate denominator in a pregnancy outcome study is all conceptions in a study base. Such a denominator is generally not achieved, as most studies observe outcome after pregnancy as clinically ascertained, or they use births or live births. Selective loss of the outcome under study before observation begins results in an underestimation of the true incidence, and it may bias exposure-outcome associations. This is the basis for the "dose-response fallacy" in reproductive epidemiology (73), and it forces the investigation of prevalence rather than incidence. It is a notable problem in studies of chromosome aberrations, birth defects, and spontaneous abortion and could produce severe bias under realistic conditions (74-76). The same problem could occur if selective termination of prenatally diagnosed birth defects is not accounted for (77). Ignoring induced abortion in a spontaneous abortion study will also lead to a denominator problem, and it could bias the results (78).

\section{Exposure}

The quality problem of exposure information is shared with other fields of epidemiology. Timing of exposure is of particular importance. The choice of time windows of exposure will always have implications as to mechanistic inferences (79), and relevant time windows are often narrow in developmental epidemiology.

\section{Study outcomes}

There are no standard diagnostic criteria for several birth defects, and diagnosis may come long after the birth.
Validation using double registration systems have demonstrated that even major birth defects are not completely ascertained $(80,81)$. Gestational age based on the last menstrual period is also error prone (82), and it could produce bias in studies in which gestational age itself or intrauterine growth retardation or small-for-gestationalage were study outcomes.

Birthweight and gestational age are continuous variables that are often dichotomized as low birthweight ( $<2500$ grams), preterm birth ( $<37$ completed weeks), and small-for-gestational-age (below the 10th percentile of birthweight for gestational age). One obvious problem with the dichotomies is the possibility to lose important information about what is going on in the left tail of the distribution curve. Besides, considering the tendency of sibship repetition of preterm birth (20), low birthweight $(20,22)$, small-for-gestational-age (23), and birthweight repetition over generations (30), this classification strategy may reflect adversity in a wrong way. Sibship and family histories indicate that a given birthweight may be normal for some newborns and adverse for others. This possibility is confirmed when perinatal mortality (as an indicator of adversity) is examined in relation to birthweight and sibship birthweight. In Norway the overall mortality for second births was 12.8 per 1000 in 1967 1984 (22); for second-born children weighing 2500 grams, perinatal mortality was only about 11 per 1000 if the older sibling had a birthweight of $2000-2499$ grams, but 85 per 1000 if the older sibling weighed $4000-4499$ grams at birth. This classification problem also operates on the population level, and it may yield distorted results when populations with differing base-line birthweight distributions are compared (83-85). There are analytic ways of overcoming the problems both on the population $(83)$ and the family $(22,23)$ level, but these are seldom used in studies addressing environmental exposures.

Proper grouping of outcomes in etiologic homogeneous categories is an ascertained problem. Preterm birth (86-88) and neural tube defects $(89-90)$ are etiologically heterogeneous, and subgroups should be considered. On the other hand, it has also been suggested that differing birth defects could have the same etiology $(91,92)$, so combining outcomes may be an option.

\section{Covariates}

Developmental health is strongly influenced by family planning and past reproductive history. In studies that address effects of parental exposure, these determinants should be regarded as covariates being considered in design and analysis. This is not an easy matter. Intuitively, it is not clear whether such covariates should be regarded as potential confounders or effect modifiers or whether they should simply be disregarded. A particular problem is the potential impact of selective fertility: the selection of women with adverse reproductive histories in 
high-order pregnancies, created by a desire for a certain family size $(9,10,93)$, in combination with the heterogeneity of risk $(10,93)$.

Socioeconomic status and social drift are obvious determinants for pregnancy outcome (94) and could crem ate comparison problems. However, the nature of the influence of these factors is still poorly understood (95). Another problem is choosing a proper reference population for occupationally exposed women. Women who have an adverse reproductive history and who are at a high base-line risk of adverse outcomes tend to stay in work and have higher opportunities of exposure than women who stay home tending children. Thus reverse causality is one component of this "infertile worker effect" (96).

Covariate information quality has received little attention. Women can have a deficient recall of past reproductive history (97) or family history as a genetic indicator (98). A comparison of information of reproductive history from 2 sources indicates that covariate information quality may have impact on the relation between environmental exposure and pregnancy outcome (15).

\section{Strategies of design and analysis}

The investigator has several options in choosing the unit of analysis in a study of pregnancy outcome (eg, the couple, the pregnancy, and the fetus or infant). Studies including several pregnancies per couple may violate the assumption of independence. Analytic tools to sort out this problem exist (32). Analysis disregarding dependence seems not to matter much under usual assumptions (32), but analytic decisions should not be taken without careful assessment of the data (33).

Handling past reproductive history in design and analysis in studies addressing parental exposure and pregnancy outcome has been debated $(31,99-101)$. Suggestions to restrict studies to first pregnancies have been forwarded, as well as suggestions to disregard reproductive history in analysis. Studying only first pregnancies would be a way to escape the problem of selective fertility that could be intermingled with the exposure under study. However, this restriction has severe disadvantages, the lack of possibility to investigate interaction between exposure and reproductive history (102) to name one. Besides, quantification suggests that selective fertility may have a limited total impact and account for less than $2 \%$ of total perinatal mortality in a modern Western society (93). The exposure under study could cause adverse outcomes in previous pregnancies, and adjustment could produce rather than resolve bias. Handling reproductive history as a covariate must be based on mechanistic assumptions that should be thoroughly considered and made clear $(100,101)$.

\section{An example: maternal smoking in pregnancy and sudden infant death syndrome}

Several factors, including maternal susceptibility, prenatal factors (growth retardation, short gestational age, maternal smoking), and postnatal factors (nonsupine sleeping position, parental smoking) are recognized or suspected causes of sudden infant death syndrome (SIDS). The impact of maternal smoking in pregnancy is naturally difficult to estimate because exposure is highly correlated with postnatal exposure; besides, prenatal smoking is a recognized cause of growth retardation $(103$, 104). In a sibship-based Swedish birth registry cohort (105) and an inter-Nordic population-based case-control study (106), it has been possible to sort out some questions albeit some are still unanswered. Maternal smoking in pregnancy is a strong determinant of SIDS, along with other prenatal factors associated with prenatal growth retardation, factors seemingly not shared by SIDS siblings. Postnatal parental smoking seems to play a modest role if any. These results have been possible due to designs that allow the mother's reproductive history to be assessed and have smoking data of sufficient quality to disentangle prenatal and postnatal exposure.

\section{The future}

In the early 1980s, optimism prevailed: epidemiology should become a powerful tool to uncover environmental and occupational causes of reproductive failure (107, 108). Expectations have not been fulfilled. Pesticides can serve as an example: numerous childhood cancer (109), fetal death (110) and birth defect (111) studies have been performed, and pesticides have been targeted as a priority research issue (1). The reward has not been substantial. In a recent editorial (112), reasons for failing advancement and future options were discussed, including the provoking question of whether epidemiologists should wait. These concerns deserve consideration at the turn of the century.

\section{Research topics}

Hopefully, there will be a shift away from risk factor epidemiology toward studies with hypotheses that are founded in biological knowledge, studies designed to investigate interference from environmental exposures on immune and endocrine regulation, and placental function, during pregnancy $(65,113)$. We have some knowledge on the role of vitamins in embryonic and fetal development, and it is warranted to investigate potential disruptions of these mechanisms by environmental exposure $(114,115)$. We need more studies to investigate geneenvironment interaction $(54,55,58-62,116)$, and malemediated effects in proper designs (117). 
Studies on fetal origins of adult disease $(4,118,119)$ should be extended to acquire knowledge on the role of parental exposure. Today, most studies are restricted to diet, and correlations and associations between fetal antecedents (birthweight, etc) and adverse conditions later in life (119). Designs should allow separate assessment of prenatal and postnatal factors $(120,121)$. As yet, parental exposure studies have concentrated on disorders in infancy $(105,106)$ and childhood cancer (109). Cancer in adult life, autoimmune disorders, allergy, and mental development could be challenging study topics. There are animal models to investigate the effects of environmental agents on germ cell development in fetal life and fertility consequences in adult life $(122,123)$. Similar hypotheses should be investigated for humans.

Joffe (34) has emphasized the virtue of studying several outcomes in concert. The problem of competing reproductive outcomes and the dose-response fallacy (73) could turn to strength if different outcomes that correspond to a single biological process were studied in the same cohort, providing mechanistic clues (124-128). Studying fertility and pregnancy outcome $(124-126)$ could be particularly rewarding. Mechanistic clues could also be achieved by studying different outcomes in subsequent pregnancies (129). This concept could also be extended to whole families and consider alleged developmental and nondevelopmental outcomes in combination (130).

\section{Designs}

During the last several years, we have witnessed progress in design and learned much about study performance, and not the least about caveats and limitations.

National, population-based cohorts provide a valuable basis for parental exposure studies. The Nordic birth registries have been operative for decades, and they provide information with which to understand the sociocultural and biological context of developmental health at the population level $(131-133)$. The establishment of sibship-based cohorts $(102,105)$ is a particular asset because the consideration of past reproductive history and selective fertility is made possible. Sibship-based cohorts have also been established in non-Nordic populations $(134,135)$. The challenge in using the registers in parental exposure studies is to obtain exposure data from other sources (102). One option is to perform case-control studies based on populations in the registers (106).

Another challenging development is biomarkers and molecular epidemiology $(136,137)$. Biomarkers in epidemiology certainly may have their problems $(138,139)$. Increased cost and feasibility problems leave case-control studies as the most realistic options, but strategies have been developed to perform studies on several levels $(140,141)$. Markers of susceptibility could prove to be the most valuable. The development of genetic susceptibility markers and designs to study gene-environment interaction have been exploding during recent years (142-145). In parental exposure studies, several traditional designs in genetic epidemiology have not been satisfactory due to the failure to obtain estimates of exposure-outcome association $(143,144)$. However, the development of gene-environment designs has led to merging with other fields of epidemiology. In particular, the "case-parent triad" case-control design seems promising since it allows separation of maternal and offspring gene impact and the assessment of imprinting (146-147). These designs have potential validity problems (148150 ), and actual experience with them is limited.

\section{Do we need a new paradigm?}

The prevailing paradigm in modern epidemiology is built on natural science. The concept of biological causality is governed by universal laws in the manner of theoretical physics. Research strategies are led by reductionism in the sense that we try to understand separate components of a process and use this information as building blocks to gain knowledge about complex systems. Susser \& Susser (151) criticized these strategies and proposed the new paradigm of ecoepidemiology. Their suggested metaphor for ecoepidemiology is Chinese boxes, to integrate epidemiologic research on the molecular and the societal level (151). The proposed paradigm shift seems attractive for developmental epidemiology because of the impact of sociocultural conditions and biology. Parental exposure research that disregards this social and biological context could end up without perspective, to be "... oriented to explaining and quantifying the bobbing of corks on the surface waters, while largely disregarding the stronger undercurrents that determine where, on average, the cluster of corks end up along the shoreline of risk" [p 634] (152). What should be done? Susser \& Susser's proposal (151) has been extensively discussed, but the designs and analytic consequences of ecoepidemiology are yet not settled (153-154). Meanwhile, we could do well to gain knowledge from different levels, in cohorts and population-based case-control studies, and escalate cooperation with molecular biologists, geneticists, and demographers.

\section{References}

1. Michal F, Grigor KM, Negro-Vilar A, Skakkebæk NE. Impact of the environment on reproductive health: executive summary. Environ Health Perspect 1993;101 suppl 2:15967.

2. Dellarco VL, Kimmel CA. Risk assessment of environmental agents for developmental toxicity: current and emerging approaches. Mutat Res 1997;396:205-18. 
3. Bonde JP. Environmental fertility research at the turn of the century. Scand J Work Environ Health 1999;25 (6 special issue):529-36.

4. Barker DPJ, editor. Fetal and infant origins of adult disease. London: BMJ Publishers, 1992.

5. Feeney G. Fertility decline in East Asia. Science 1994;266:1518-23.

6. Medical Birth Registry of Norway. Annual report 1990. Bergen (Norway): Medical Birth Registry of Norway, 1991.

7. Westergaard T, Wohlfahrt J, Aaby P, Melbye M. Population based study of rates of multiple pregnancies in Denmark, 1980-94. BMJ 1997;314:775-9.

8. Hecht BR. The impact of assisted reproductive technology on the incidence of multiple gestation. In: Keith LG, Papiernik E, Keith DM, Luke B, editors. Multiple pregnancy: epidemiology, gestation and perinatal outcome. New York (NY): Parthenon Publishing Group, 1995:175-90.

9. Bjerkedal T, Erickson JD. Association of birth outcome with subsequent fertility. Am J Obstet Gynecol 1983;147:399404.

10. Wilcox AJ, Gladen B. Spontaneous abortion: the role of heterogeneous risk and selective fertility. Early Hum Dev 1982;7:165-78.

11. Record RG, Armstrong E. The influence of the birth of a malformed child on the mother's further reproduction. $\mathrm{Br} \mathrm{J}$ Prev Soc Med 1975;29:267-73.

12. Yerushalmy J Bierman JM, Kemp DH, Connor A, French FE. Longitudinal studies of pregnancy on the island of Kauai, territory of Hawaii, I: analysis of previous reproductive history. Am J Obstet Gynecol 1956;71:80-96.

13. James WH. Notes towards an epidemiology of spontaneous abortion. Am J Hum Genet 1963;15:223-40.

14. Risch HA, Weiss NS, Clarke EA, Miller AB. Risk factors for spontaneous abortions and its recurrence. Am $\mathbf{J}$ Epidemiol 1988; 128:420-30.

15. Kristensen P, Irgens LM. Maternal reproductive history: a registry based comparison of previous pregnancy data derived from maternal recall and data obtained during the actual pregnancy. Acta Obstet Gynecol Scand. Paediat Perinat Epidemiol. In press.

16. Bross DS, Shapiro S. Direct and indirect associations of five factors with infant mortality. Am J Epidemiol 1982;115:7891.

17. Kiely JL, Paneth N, Susser M. An assessment of the effect of maternal age and parity in different components of perinatal mortality. Am J Epidemiol 1986;123:444—54.

18. Skjærven R, Irgens LM, Lie RT, Bjerkedal T. Parity specific perinatal mortality: a longitudinal study based on sibships. Paediat Perinat Epidemiol 1987;1:163-83.

19. Pickering RM, Deeks JJ. Risk of delivery during the 20th to the 36th week of gestation. Int J Epidemiol 1991;20:456-66.

20. Bakketeig LS, Hoffman HJ, Harley EE. The tendency to repeat gestational age and birth weight in successive births. Am J Obstet Gynecol 1979;135:1086-103.

21. Mogren I, Stenlund H, Högberg U. Recurrence of prolonged pregnancy. Int J Epidemiol 1999;28:253-7.

22. Skjærven R, Wilcox AJ, Russell D. Birthweight and perinatal mortality of second births conditional on weight of the first. Int J Epidemiol 1988;17:830-8.

23. Skjærven R, Bakketeig LS. Classification of small-for-gestational age births: weight-by-gestational standards of second births conditional on the size of the first. Paediat Perinat Epidemiol 1989;3:432 - 47

24. Coulam CB, Wagenknecht D, McIntyre JA, Faulk WP, An- negers JF. Occurrence of other reproductive failures among women with recurrent spontaneous abortion. Am J Reprod Immunol 1991;25:96-8.

25. Paz J, Otaño L, Gadow E, Castilla EE. Previous miscarriage and stillbirth as risk factors for other unfavourable outcomes in the next pregnancy. Br J Obstet Gynaecol 1992;99:80812.

26. Goldenberg RL, Mayberry SK, Copper RL, Dubard MB, Hautch JC. Pregnancy outcome following a second-trimester loss. Obstet Gynecol 1993;81:444—6.

27. Lie RT, Wilcox AJ, Skjærven R. A population-based study of the risk of recurrence of birth defects. $\mathrm{N}$ Engl J Med 1994:331:1-4.

28. Emanuel I, Filakti H, Alberman E, Evans SJW. Intergenerational studies of human birthweight from the 1958 birth cohort, 1: evidence for a multigenerational effect. $\mathrm{Br} \mathrm{J}$ Obstet Gynaecol 1992;99:67-74.

29. Magnus P, Bakketeig LS, Skjærven R. Correlations of birth weight and gestational age across generations. Ann Hum Biol 1993;20:231-8.

30. Skjærven R, Wilcox AJ, Øyen N, Magnus P. Mothers' birth weight and survival of their offspring: population based study. BMJ 1997;314:1376-80.

31. Gladen BC. On the role of "habitual aborters" in the analysis of spontaneous abortion. Stat Med 1986;5:557-64.

32. Watier L, Richardson S, Hémon D. Accounting for pregnancy dependency in epidemiologic studies of reproductive outcomes. Epidemiology 1997;8:629-36.

33. Hertz-Picciotto I. A new insight into pregnancy loss [editorial]. Epidemiology 1997;8:611-2.

34. Joffe M. Detection of agents causing genetic or reproductive damage [editorial]. Br J Ind Med 1992;49:1—4.

35. Vainio H. Carcinogenesis and teratogenesis may have common mechanisms. Scand J Work Environ Health 1989; 15:13-7.

36. Tomatis L. Transgeneration carcinogenesis: a review of the experimental and epidemiological evidence. Jpn J Cancer Res 1994;85:443-54.

37. Olshan AF, Faustman EM. Male-mediated developmental toxicity. Reproductive Toxicol 1993;7:191-202.

38. Colie CF. Male mediated teratogenesis. Reproductive Toxicol 1993:7:3-9.

39. Chandley AC. On the parental origin of de novo mutation in man. J Med Genet 1991;28:217-23.

40. Shelby MD, Bishop JB, Mason JM, Tindall KR. Fertility, reproduction, and genetic disease: studies on the mutagenic effects of environmental agents on mammalian germ cells. Environ Health Perspect 1993;100:283—91.

41. Falls JG, Pulford DJ, Wylie AA, Jirtle RL. Genomic imprinting: implications for human disease. Am J Pathol 1999;154:635-47.

42. Haig D. Altercation of generations: genetic conflicts of pregnancy. Am J Reprod Immunol 1996;35:226-32.

43. LeFebvre L, Viville S, Barton SC, Ishino F, Keverne FB, Surani MA. Abnormal maternal behaviour and growth retardation associated with loss of the imprinted gene Mest. Nat Genet 1998;20:163-9.

44. Wihman IL, Carlström K, Faxen M. Insulin-like growth factor-I in women with hydatidiform mole and in normal pregnancy. Obstet Gynecol 1998;92:431-4.

45. Lie RT, Rasmussen S, Brunborg H, Gjessing HK, Lie-Nielsen E, Irgens LM. Fetal and maternal contributions to risk of preeclampsia: population based study. BMJ 1998;316:1343-7.

46. Graves JAM. Genomic imprinting, development and disease 
- is pre-eclampsia caused by a maternally imprinted gene? Reprod Fertil Dev 1998;10:23-9.

47. Suk WA, Collman GW. Genes and the environment: their impact on children's health. Environ Health Perspect 1998;106 suppl 3:817-20.

48. Medical Research Council Vitamin Study Research Group. Prevention of neural tube defects: results of the Medical Research Council vitamin study. Lancet 1991;338:131-7.

49. Czeizel AE, Dudas I. Prevention of the first occurrence of neural-tube defects by periconceptional vitamin supplementation. N Engl J Med 1992;327:1832-5.

50. Mills JL, McPartlin JM, Kirke PN, Lee YJ, Conley MR, Weir DG, et al. Homocysteine metabolism in pregnancies complicated by neural-tube defects. Lancet 1995;345:149—51.

51. van der Put NMJ, Steegers-Theunissen RPM, Frosst P, Trijbels FJM, Eskes TKAB, van den Heuvel LP, et al. Mutated methylenetetrahydrofolate reductase as a risk factor for spina bifida. Lancet 1995;346:1070-1.

52. Shaw GM, Lammer EJ, Wasserman CR, O'Malley CD, Tolarova MM. Risks of orofacial clefts in children born to women using multivitamins containing folic acid periconceptionally. Lancet 1995;345:393-6.

53. Hayes C, Werler MM, Willett WC, Mitchell AA. Case-control study of periconceptional folic acid supplementation and oral clefts. Am J Epidemiol 1996;143:1229-34.

54. Shaw GM, Wasserman CR, Lammer EJ, O'Malley CD, Murray JC, Basart AM, et al. Orofacial clefts, parental cigarette smoking, and transforming growth factor-alpha gene variants. Am J Hum Genet 1996;58:551-61.

55. Shaw GM, Lammer EJ. Incorporating molecular genetic variation and environmental exposures into epidemiologic studies of congenital anomalies. Reproductive Toxicol 1997;11:27580.

56. Shaw GM, Wasserman CR, Murray JC, Lammer EJ. Infant TGF-alpha phenotype, orofacial clefts, and maternal periconceptional multivitamin use. Cleft Palate-Craniofacial J 1998;35:366-70.

57. Shaw GM, Rozen R, Finnell RH, Todoroff K, Lammer EJ. Infant C677T mutation in MTHFR, maternal periconceptional vitamin use, and cleft lip. Am J Med Genet 1998;80:1968.

58. Hwang S-J, Beaty TH, Panny SR, Street NA, Joseph JM, Gordon S, et al. Association study of transforming growth factor alpha (TGF $\alpha$ ) TaqI polymorphism and oral clefts: indication of gene-environment interaction in a population-based sample of infants with birth defects. Am J Epidemiol 1995;141:629-36.

59. Beaty TH, Maestri NE, Hetmanski JB, Wyszynski DF, Vanderkolk CA, Simpson JC, et al. Testing for interaction between maternal smoking and TGFA genotype among oral cleft cases born in Maryland 1992-1996. Cleft PalateCraniofacial J 1997;34:447-54.

60. Christensen K, Olsen J, Nørgaard-Pedersen B, Basso O, Støvring H, Milhollin-Johnson L, et al. Oral clefts, transforming growth factor alpha gene variants, and maternal smoking: a population-based case-control study in Denmark, 19911994. Am J Epidemiol 1999;149:248 — 55.

61. Romitti PA, Lidral AC, Munger RG, Daack-Hirsch S, Burns TL, Murray JC. Candidate genes for nonsyndromic cleft lip and palate and maternal cigarette smoking and alcohol consumption: evaluation of genotype-environment interactions from a population-based case-control study of orofacial clefts. Teratology 1999;59:39-50.

62. Maestri NE, Beaty TH, Hetmanski J, Smith EA, McIntosh I,
Wyszynski DF, et al. Application of transmission disequilibrium tests to nonsyndromic oral clefts: including candidate genes and environmental exposures in the models. Am J Med Genet 1997;73:337-44.

63. Mitchell LE. Genetic epidemiology of birth defects: nonsyndromic cleft lip and neural tube defects. Epidemiol Rev 1997;19:61-8.

64. Cross JC, Werb Z, Fisher SJ. Implantation and the placenta; key pieces of the development puzzle. Science 1994; 266:1508-18.

65. Sharpe RM, Skakkebæk NE. Are oestrogens involved in falling sperm counts and disorders of the male reproductive tract? Lancet 1993;341:1392-5.

66. Golden RJ, Noller KL, Titus-Ernstoff L, Kaufman RH, Mittendorf R, Stillman R, et al. Environmental endocrine modulators and human health: an assessment of the biological evidence. Crit Rev Toxicol 1998;28:109-227.

67. Wegmann TG, Lin H, Guilbert L, Mosmann TR. Bidirectional cytokine interactions in the maternal-fetal relationship: is successful pregnancy a $T_{H} 2$ phenomenon? Immunol Today $1993 ; 14: 353-6$

68. Marzi M, Vigano A, Trabattoni D, Villa ML, Salvaggio A, Clerici $E$, et al. Characterization of type 1 and type 2 cytokine production profile in physiologic and pathologic human pregnancy. Clin Exp Immunol 1996;106:127-33.

69. Hill JA. Immunologic factors in spontaneous abortion. In: Bronson RA, Alexander NJ, Anderson DJ, Branch DW, Kutteh WH. Reproductive immunology. Cambridge (MA): Blackwell Science, 1996:433-42.

70. Lockhood CJ, Rand JH. The immunobiology and obstetrical consequences of antiphospholipid antibodies. Obstet Gynecol Surv 1994;49:432—41.

71. Christiansen OB. Epidemiological, immunogenetic and immunotherapeutic aspects of unexplained recurrent miscarriage. Dan Med Bull 1997;44:396-424.

72. Weinberg CR, Wilcox AJ. Reproductive epidemiology. In: Rothman KJ, Greenland S, editors. Modern epidemiology. 2nd Edition. Philadelphia (PA): Lippincott-Raven, 1997:585-608.

73. Selevan SG, Lemasters GK. The dose-response fallacy in human reproductive studies of toxic exposures. J Occup Med 1987;29:451-4.

74. Hook EB, Regal RR. Conceptus viability, malformation, and suspect mutagens or teratogens in humans: the Yule-Simpson paradox and implications for inferences of causality in studies of mutagenicity or teratogenicity limited to human livebirths. Teratology 1991;43:53-9.

75. Khoury MJ, Flanders WD, James LM, Erickson JD. Human teratogens, prenatal mortality, and selection bias. Am J Epidemiol 1989;130:361-70.

76. Stein Z, Susser M, Warburton D, Wittes J, Kline J. Spontaneous abortion as a screening device: the effect of fetal survival on the incidence of birth defects. Am J Epidemiol 1975;102:275-90.

77. Velie EM, Shaw GM. Impact of prenatal diagnosis and elective termination on prevalence and risk estimates of neural tube defects in California, 1989-1991. Am J Epidemiol 1996;144:473-9.

78. Olsen J. Calculating risk ratios for spontaneous abortions: the problem of induced abortions. Int J Epidemiol 1984;13:34750.

79. Rothman KJ. Induction and latent period. Am J Epidemiol 1981;114:253-9.

80. Lie RT, Heuch I, Irgens LM. Maximum likelihood estimation 
of the proportion of congenital malformations using double registration systems. Biometrics 1994;50:433 - 44.

81. Ericson A, Källén B, Winberg J. Surveillance of malformations at birth: a comparison of two record systems run in parallel. Int J Epidemiol 1977;6:35-41.

82. Gjessing HK, Skjærven R, Wilcox AJ. Errors in gestational age: evidence of bleeding early in pregnancy. Am J Public Health 1999;89:213-8.

83. Wilcox AJ, Russell IT. Bitthweight and perinatal mortality, III: toward a new method of analysis. Int J Epidemiol 1986;15:188-96.

84. Wilcox A, Skjærven R, Buekens P, Kiely J. Birth weight and perinatal mortality: a comparison of the United States and Norway. J Am Med Assoc 1995;273:709-11.

85. Kiely JL, Susser M. Preterm birth, intrauterine growth retardation, and perinatal mortality [editorial]. Am J Public Health 1992;82:343-5.

86. Savitz DA, Blackmore CA, Thorp JM. Epidemiologic characteristics of preterm delivery: etiologic heterogeneity. Am J Obstet Gynecol 1991;164:467-71.

87. Berkowitz GS, Blackmore-Prince C, Lapinski RH, Savitz DA Risk factors for preterm birth subtypes. Epidemiology 1998;9:279-85.

88. Ananth CV, Savitz Da, Luther ER, Bowes WA Jr. Preeclampsia and preterm birth subtypes in Nova Scotia, 1986 to 1992. Am J Perinatol 1997;14:17-23.

89. Copp AJ. Genetic models of mammalian neural tube defects. Ciba Found Symp 1994;181:118-43.

90. Källén B, Robert E, Harris J. Associated malformations in infants and fetuses with upper and lower neural tube defects. Teratology 1998;57:56-63.

91. Khoury MJ, Moore CA, James LM, Cordero JF. The interaction between dysmorphology and epidemiology: methodolog ic issues of lumping and splitting. Teratology 1992;45:1338.

92. Weinberg CR, Skjærven R, Wilcox AJ. Statistical evidence for shared transient causes of anatomically distinct birth defects. Stat Med 1996;15:2029-36.

93. Skjærven R, Wilcox AJ, Lie RT, Irgens LM. Selective fertility and the distortion of perinatal mortality. Am J Epidemiol 1988;128:1352-63.

94. Basso O, Olsen J, Christensen K. Study of environmental, social, and paternal factors in preterm delivery using sibs and half-sibs: a population-based study in Denmark. J Epidemiol Community Health 1999;53:20-3.

95. Wilcox AJ, Skjærven R, Irgens LM. Harsh social conditions and perinatal survival: an age-period-cohort analysis of the World war II occupation of Norway. Am J Public Health 1994;84:1463-7.

96. Joffe M. Biases in research on reproduction and women's work. Int J Epidemiol 1985;14:118-23.

97. Wilcox AJ, Horney LF. Accuracy of spontaneous abortion recall. Am J Epidemiol 1984;120:727-33.

98. Khoury MJ, Flanders WD. Bias in using family history as a risk factor in case-control studies of disease. Epidemiology 1995;6:511-9.

99. Olsen J. Options in making use of pregnancy history in planning and analysing studies of reproductive failure. J Epidemiol Community Health 1994;48:171-4.

100. Weinberg CR. Toward a clearer definition of confounding. Am J Epidemiol 1993;137:1-8.

101. Nurminen T. On adjusting for the outcome of previous pregnancies in epidemiologic reproductive studies. Epidemiology 1995;6:84-6.
102. Kristensen P, Irgens LM, Bjerkedal T. Environmental factors, reproductive history, and selective fertility in farmers' sibships. Am J Epidemiol 1997;145:817—25

103. Golding J. Sudden infant death syndrome and parental smoking - a literature review. Paediatr Perinat Epidemiol 1997;11:67-77.

104. Spiers PS. Invited commentary: disentangling the separate effects of prenatal and postnatal smoking on the risk of SIDS. Am J Epidemiol 1999;149:603-6.

105. Øyen N, Haglund B, Skjærven R, Irgens LM. Maternal smoking, birthweight and gestational age in sudden infant death syndrome (SIDS) babies and their surviving siblings. Paediat Perinat Epidemiol 1997;11 suppl 1:84-95.

106. Alm B, Milerad J, Wennergren G, Skjærven R, Øyen N, Norvenius $G$, et al. A case-control study of smoking and sudden infant death syndrome in the Scandinavian countries, 1992 to 1995: The Nordic Epidemiological SIDS Study. Arch Dis Child 1998;78:329-34.

107. Lockey JE, Lemasters GK, Keye WR Jr, editors. Reproduction: the new frontier in occupational and environmental health research. New York (NY): Alan R Liss, 1984.

108. Whorton MD. Adverse reproductive outcomes: the occupational health issue of the 1980s [editorial]. Am J Public Health 1983;73:15-6.

109. Zahm SH, Ward MH. Pesticides and childhood cancer. Environ Health Perspect 1998;106 suppl 3:893-908.

110. Arbuckle TE, Sever LE. Pesticide exposures and fetal death: a review of the epidemiologic literature. Crit Rev Toxicol 1998;28:229-70.

111. Garcia AM. Occupational exposure to pesticides and congenital malformations: a review of mechanisms, methods, and results. Am J Ind Med 1998;33:232—40.

112. Kogevinas M, Sala M. Pesticides and congenital malformations - how many studies will it take to reach a conclusion? [editorial]. Scand J Work Environ Health 1998;24:445-7.

113. Gerhard I, Waibel S, Daniel V, Runnebaum B. Impact of heavy metals on hormonal and immunological factors in women with repeated miscarriages. Hum Reprod Update 1998;4:301-9.

114. Wu T, Buck G, Mendola P. Maternal cigarette smoking, regular use of multivitamin/mineral supplements, and risk of fetal death: the 1988 National Maternal and Infant Health Survey. Am J Epidemiol 1998;148:215-21.

115. Sakanashi TM, Rogers JM, Fu SS, Connelly LE, Keen CL. Influence of maternal folate status on the developmental toxicity of methanol in the CD-1 mouse. Teratology 1996;54:198-206.

116. Mendola P, Moysich KB, Freudenheim JL, Shields PG, Schisterman EF, Graham S, et al. Risk of recurrent spontaneous abortion, cigarette smoking, and genetic polymorphisms in NAT2 and GSTM1. Epidemiology 1998;9:666-8.

117. Hjollund NHI, Bonde JPE, Jensen TK, Henriksen TB, Andersson A-M, Kolstad HA, et al. Male mediated spontaneous abortion: a follow-up study of spouses to stainless steel welders. Scand J Work Environ Health. In press.

118. Barker DJP. The fetal origins of type 2 diabetes mellitus. Ann Int Med 1999;130:322 - 4 .

119. Joseph KS, Kramer MS. Review of the evidence on fetal and early childhood antecedents of adult chronic disease. Epidemiol Rev 1996;18:158-74.

120. - Heart disease: in the beginning [editorial]. Lancet 1992;339:1386-8.

121. Robinson RJ. Is the child father of the man? [editorial]. BMJ 1992;304:789-90. 
122. Wide M, d'Argy R. Effect of inorganic lead on the primordial germ cells in the mouse embryo. Teratology 1986;34:20712.

123. Kristensen P, Eilertsen E, Einarsdóttir E, Haugen AA, Skaug $\mathrm{V}, \emptyset_{\mathrm{v} r e b} \emptyset \mathrm{S}$. Fertility in mice after prenatal exposure to benzo[a]pyrene and inorganic lead. Environ Health Perspect 1995; 103:588-90.

124. Correa A, Gray RH, Cohen R, Rothman N, Shah F, Seacat H, et al. Ethylene glycol ethers and risks of spontaneous abortion and subfertility. Am J Epidemiol 1996;143:707-17.

125. Henriksen TB, Baird DD, Olsen J, Hedegaard M, Secher NJ, Wilcox AJ. Time to pregnancy and preterm delivery. Obstet Gynecol 1997;89:594-9.

126. Baird DD, Wilcox AJ, Kramer MS. Why might infertile couples have problem pregnancies? [commentary]. Lancet 1999;353:1724-5.

127. Cnattingius S. Maternal age modifies the effect of maternal smoking on intrauterine growth retardation but not on late fetal death and placental abruption. Am $\mathbf{J}$ Epidemiol 1997; 145:319-23.

128. Torfs CP, Christianson RE. Maternal risk factors and major associated defects in infants with Down syndrome. Epidemiology 1999;10:264-70.

129. Sheiner E, Katz M, Fraser D, Gohar J, Carmi R. The relationship between congenital cardiovascular malformations and spontaneous abortion in preceding pregnancy. Paediat Perinat Epidemiol 1998;12:128-35.

130. Kroman N, Frisch M, Olsen JH, Westergaard T, Melbye M. Oestrogen-related cancer risk in mothers of testicular-cancer patients. Int J Cancer 1996;66:438-40.

131. Bakketeig LS. Perinatal epidemiology - a Nordic challenge. Scand J Soc Med 1991;19:145-7.

132. Cnattingius S, Ericson A, Gunnarskog J, Källén B. A quality study of a medical birth registry. Scand J Soc Med 1990;18:143-8.

133. Nordic Medico-Statistical Committee. Births and infant mortality in the Nordic countries. Copenhagen: Nomesko, 1993. Publication no 39.

134. McCarthy BJ, Berendes HW. Pregnancy outcome investigation for the 21st century [commentary]. Paediat Perinat Epidemiol 1997; 11 suppl 1:2-4.

135. Herman AA, McCarthy BJ, Bakewell JM, Ward RH, Mueller BA, Maconochie NE, et al. Data linkage methods used in maternally-linked birth and infant death surveillance data sets from the United States (Georgia, Missouri, Utah and Washington State), Israel, Norway, Scotland and Western Australia. Paediat Perinat Epidemiol 1997;11 suppl 1:5-22.

136. Hulka BS, Wilcosky TC, Griffith JD, editors. Biological markers in epidemiology. New York (NY): Oxford University Press, 1990

137. Hatch MC, Friedman-Jimenez G. Using reproductive effect markers to observe subclinical events, reduce misclassification, and explore mechanism. Environ Health Perspect 1991;90:255-9.

138. Wilcox AJ. Molecular epidemiology: collision of two cultures [commentary]. Epidemiology 1995;6:561-2.

139. Pearce N, de Sanjose S, Boffetta P, Kogevinas M, Saracci R,
Savitz D. Limitations of biomarkers of exposure in cancer epidemiology [commentary]. Epidemiology 1995;6:190_4.

140. Savitz DA, Bornschein RL, Ambler RW, Bove FI, Edmonds LD, Hanson JW, et al. Assessment of reproductive disorders and birth defects in communities near hazardous chemical sites, I: birth defects and developmental disorders. Reproductive Toxicol 1997;11:223-30.

141. Scialli AR, Swan SH, Ambler RW, Baird DD, Eskenazi B, Gist $\mathrm{G}$, et al. Assessment of reproductive disorders and birth defects in communities near hazardous chemical sites, II: female reproductive disorders. Reproductive Toxicol $1997 ; 11: 231-42$.

142. Khoury MJ, Yang Q. The future of genetic studies of complex human diseases: an epidemiologic perspective [commentary]. Epidemiology 1998;9:350-4.

143. Yang Q, Khoury MJ. Evolving methods in genetic epidemiology, III: gene-environment interaction in epidemiologic research. Epidemiol Rev 1997;19:33 - 43.

144. Andrieu N, Goldstein AM. Epidemiologic and genetic approaches in the study of gene-environment interaction: an overview of available methods. Epidemiol Rev 1998;20:13747.

145. Umbach DM, Weinberg CR. Designing and analysing casecontrol studies to exploit independence of genotype and exposure. Stat Med 1997;16:1731—43

146. Wilcox AJ, Weinberg CR, Lie RT. Distinguishing the effects of maternal and offspring genes through studies of "caseparent triads". Am J Epidemiol 1998;148:893-901.

147. Weinberg CR, Wilcox AJ, Lie R'T. A log-linear approach to case-parent triad data: assessing effects of disease genes that act directly or through maternal effects and that may be subject to parental imprinting. Am J Hum Genet Epidemiol $1998 ; 62: 969-78$

148. Garcia-Closas M, Thompson WD, Robins JM. Differential misclassification and the assessment of gene-environment interactions in case-control studies. Am J Epidemiol 1998; $147: 426-33$.

149. Hwang S-J, Beaty TH, Liang K-Y, Coresh J, Khoury MJ. Minimum sample size estimation to detect gene-environment interaction in case-control designs. Am J Epidemiol 1994; 140:1029-37.

150. Romitti PA, Munger RG, Murray JC, Daak-Hirsch S, Hanson JW, Burns TL. The effect of follow-up on limiting nonparticipation bias in genetic epidemiologic investigations. Eur J Epidemiol 1998;14:129_38.

151. Susser M, Susser E. Choosing a future for epidemiology. II. From black boxes to Chinese boxes. Am J Public Health 1996;86:674-8

152. McMichael AJ. The health of persons, populations, and planets: epidemiology comes full circle. Epidemiology 1995; $6: 633-6$.

153. Poole C, Rothman KJ. Our conscientious objection to the epidemiology wars. Epidemiol Community Health 1998; 52:613-4.

154. Diez-Roux AV. Bringing context back into epidemiology: variables and fallacies in multilevel analysis. Am J Public Health 1998;88:216-22. 